\title{
The Effect of Using YouTube on Developing Elementary Students Vocabulary
}

\author{
Afnan Mohammed AL-Ameri \\ School of Arts and Languages, Jadara University, Jordan \\ Luqman Rababah (Correspondence) \\ School of Arts and Languages, Jadara University, Jordan \\ E-mail: Rababah80@gmail.com
}

Received: February 2, 2020

Accepted: April 1, 2020 Published: April 3, 2020

doi:10.5296/elr.v6i1.16796

URL: https://doi.org/10.5296/elr.v6i1.16796

\begin{abstract}
The study aims at identifying the importance of using technology especially YouTube in the development of English vocabulary among elementary school students. Further, the current study aims at identifying students' levels of ability through the use of technology and modern methods used in education, specifically the use of YouTube. To achieve these objectives, a sample of thirty of fifth grade female students was chosen and divided equally and randomly into two groups. Pre-test and post-test method were used to measure the learning ability of these two groups. The results revealed that the use of YouTube increased the ability of students in learning new vocabulary which show that technology has positive effects on learning process. Based on these findings, it is recommended to integrate technological aids on the classrooms.
\end{abstract}

Keywords: New teaching materials, YouTube, Language acquisition, Vocabulary

\section{Introduction}

Technological innovations provide new ways to develop the teaching and learning process. Currently many educators look toward technology as a means to enhance instructions to increase students' achievements. The social media in recent years has been considered an effective tool to supplement the traditional teaching methods (Buzzetto-More, 2012). Variety of technologies is designed to support the learning process, such as interactive modern teaching techniques. Modern teaching techniques have been the most visible development in teaching in recent years. Advantages of the modern teaching techniques have encouraged schools to implement such tools into instruction (Bonk, 2008). 
Using modern teaching technology is a way to develop English language vocabulary allowing both the teacher and students to interact with technology in whole class activities. However, it is important to understand the impact of this new technology on the pedagogical process, and how it is implemented and interpreted by teachers. Educators and researchers have recommended English teachers to use modern methods and techniques in teaching vocabulary to elementary students, in addition, digital age students prefer something that is related with technology such as YouTube (Azkia \& Ahmad, 2017).

Recently, Ministry of Education (MoE) in Jordan has provided schools with technological aids to enhance students' learning experience. Therefore, an increasing number of ICT tools in Jordan schools provide teachers with the opportunity to teach in interactive learning environment.

According to the researcher's experience, teaching English as a foreign language in Jordan has much interest in ministry of education because it is global language. Although, there are many qualified teachers for teaching English in all school levels and the much interest designing cervical, many students are weak in using English language, grammar, reading, writing, and speaking (Bali, 2017).

Most of the students lack English vocabulary which hinders them from reading, writing, and communicating with others by using English vocabulary. These reasons motivated the researcher to look for new methods of teaching vocabulary to implement in all stages.

It is widely perceived that modern teaching techniques improve the teaching and learning process as well as the education process, but there is little research on how modern teaching techniques improve vocabulary attainment in English language of elementally students in Jordanian context. Hence, this study is an attempt to explore the significance of using technology especially YouTube on improving the vocabulary learning process of fifth grade students. YouTube has the ability to increase the vocabulary acquisition among learners (Kabooha \& Elyas, 2018).

One can not dispute the fact that Modern Teaching Techniques change the way instruction is provided in our classrooms. Traditional classrooms with traditional ways are restrictive and lack flexibility, and despite the positive reaction by many educators, some teachers are hesitant to embrace the technology and this detects from students learning. This study aims to investigate whether Modern Teaching Techniques play a constructive role in English language classrooms and their possible effect on vocabulary learning in Jordanian schools, and how modern teaching techniques are compared to the traditional technique to promote awareness of the importance of modern teaching techniques. In addition, the way teachers use the modern teaching techniques is an essential component of its success in learning enhancement. In this respect teachers' practices and attitudes towards modern teaching techniques in relation to English vocabulary teaching will be examined.

This study is expected to answer the follow questions:

1). Does the experimental group show a greater vocabulary gain than the control group?

2). Does a modern teaching technique use help and improve elementary students' vocabulary knowledge? 


\section{М Macrothink}

The study has the following limitations:

First, the experimental study was carried out in only one public school for female students in Jordan. Moreover, the sample of the study is limited to only 30 female fifth grade students which limits the possibility of generalization of the results.

\section{Related Studies}

This chapter provides a literature review of some studies on the use of technology, specifically YouTube in the development of English vocabulary for primary students. The theoretical framework will be presented as a concept for modern teaching techniques and YouTube, and the relevant studies are provided.

The teaching process is one of the most difficult and complicated tasks. It inevitably needs more challenges, art, and creativity to serve the increasing demands of students. Most of the teachers have always looked for a proper and effective environment for students' to make them gain more interesting learning. Therefore, Richards (2001) mentions that authentic materials which are the use of different technologies materials like, videos, auditory aids that have been widely introduced as one of the best teaching tools that play a powerful function in the educational platform, which constantly thriving to maximize EFL learners practice and support teachers' to developing their activities in the natural and clear way. Indeed, authentic materials play a significant use in education that serves both the teachers and the learners as a means of learning.

Integration of technology into different fields of life is one of the most important reasons for the advancement of societies both economically and educationally. According to Solanki and Phil (2012), using traditional teaching method has hindered students from developing their learning abilities; tradition teaching methods do not include new techniques to learning English making students as passive recipients of the knowledge. Thus, it is very necessary to substitute these traditional methods with the new ones that use technological aids. YouTube is very significant means of teaching and the creative teachers could use it in improving listening and speaking in the classrooms.

According to Watkins and Wilkins (2011), the teachers do conversation analysis which is very useful activity that increases the students' awareness of the effective conversation techniques. Using YouTube in teaching enhances the importance of interaction between teacher and students, the most important features of using YouTube in teaching is to improve students' ability to listen and speak and also develop their communicative with others (Solanki \& Phil, 2012).

In Jordan, there has been an interest in examining the technological aids in teaching. For example, Mubaslat (2012) explains that using games in education is very important and it positively encourages the students to achieve better with vocabulary learning in particular and other skills in general. The reason why games are considered effective learning and are that games can spur motivation and encourage them to interact. Mei and Yu-jing (2010) said that using games in education are fun and children like them games children experiment, discover and also interact with their environment.

Further, using games for students as helping tool in teaching and learning can learn English "the way children learn their mother tongue without being aware they students, thus without 
stress" (Mubaslat, 2012, p. 22).

The teacher must have sufficient experience in selecting the appropriate game with the students and class that has learned, so that the game is suitable for the age of the student and the curriculum and the game must be more than just fun. A game should give students a chance to learn, practice, or review specific language material and keep all of the students focused on the language and keep them involved and interested.

The simple fact that children have to sit many hours listening and focus to what their teachers say, without doing anything and witting what they understanding in their notebooks, but when they learn by using games they do something different, they running around, beating each other, etc.

Most of the previous studies have focused on the importance of using different teaching methods (Mubaslat, 2012; Eaton, 2010). However, few of them have focused on impact of using YouTube in schools to develop the vocabulary of elementary students.

\section{Research Methodology}

This study has adopted a quantitative experimental design. Thirty female of fifth grade students from a public school were chosen as a sample of this study. The sample was divided into two groups; control group and experimental group. The control group received instruction through traditional method such as a white board and textbooks, while the experiential group received instructing through new teaching method which is (YouTube).

\subsection{Population and Sample of the Study}

The population of the study consists of all students at the elementary stage in Almashare public schools. The students take compulsory vocabulary course in the same semester. All participants are Jordanians, and their ages ranged between 10 to 11 years old. They have been studying English for roughly four years. The sample of the study includes 30 fifth grade female students at Al-Masharaa public school as shown in the following table.

Table 1. Characteristics of the study sample

\begin{tabular}{llll}
\hline Gender & Age & Educational level & Nationality \\
\hline Female & 11 & Fifth grade & Jordanians \\
\hline
\end{tabular}

\subsection{Research Instrument}

The instruments used in this study are pre-test and post-test. Curriculum based achievement test was developed by the researcher to assess students' vocabulary achievement in the pre-test and post-test. The tests parallel in terms of items difficulty level and patterns and consists of 10 items; multiple choice, matching columns items and classifying items with a perfect score of 20. The pre-test and post-test was based on the units taught to the students. A pre-test was designed to a certain initial equivalence of the two groups before the treatment variable is introduced in to the research sitting. To verify the equivalence of the two groups pre-test and post-test scores, a T-test for significant differences between two independent 
states was used to identify the differences between the averages of the experimental group and the control group. Both experimental and control groups sat for a post-test one semester interaction with and without the YouTube, the students' performance was compared in term of vocabulary development.

\subsection{Data Collection and Analysis}

First, pre-test and a post-test were prepared for both groups (control group and experimental group) and another two tests to be given to the students every week for two weeks. Second, the tests were given to the students after teaching them the valuably using two different teaching methods. Finally the results of both groups were compared.

The collected data were analyzed using the Statistical Package for the Social Sciences (SPSS). For the evaluation of the differences between the groups, different statistical tests such as: Independent sample T-test, Paired sample T-test, ANOVA test were used.

\section{Results and Discussion}

This section presents the results of current study highlighting the effects of using modern technology methods of teaching and learning on EFL students. In this chapter, the descriptive tables and graphs are presented and followed by inferential statistics.

The pie chart below shows the distribution of both groups (experimental and control), the sample of both groups was 30 female students from fifth grade, the number of respondents in experimental group was 15 students, and the number of respondents in control group was 15 students.

Table 2. Frequency distribution of sample group based on experimental and control group

\begin{tabular}{|c|c|c|c|c|}
\hline Group & Frequency & Percen & Valid Percent & Cumulative Percent \\
\hline Experimental & 15 & 50.0 & 50.0 & 50.0 \\
\hline Control & 15 & 50.0 & 50.0 & 100.0 \\
\hline Total & 30 & 100.0 & 100.0 & \\
\hline
\end{tabular}

\subsection{Research Question One: Does the Experimental Group Show a Greater Vocabulary Gain} Than the Control Group?

The first research question intended to check if there is a significant difference in vocabulary competence between pretest and posttest mean values for students in both cases (traditional method and modern method).

A pre-test was conducted to ensure the equivalence in both the experimental group and control group in their proficiency of English and their ability to recognize and comprehend the targeted work. This test also used to find out if there were any significant differences between the pre-test scores of the students in the control group and experimental group. The following table shows the analysis of the pre-test scores of the control group and experimental group. 
Table 3. Analysis of the pre-test scores of experimental and control group

\begin{tabular}{llllll}
\hline Pre-Test & \multicolumn{6}{l}{} & & \\
\hline Group & $\mathrm{N}$ & Mean & SD & T. Value & P. Value \\
Control & 15 & 15.33 & 2.093 & & \\
Experimental & 15 & 15.07 & 2.219 & 0.307 & 0.764 \\
\hline
\end{tabular}

The results of t-test show that there was no significant difference between the control group $(\mathrm{m}=15.33)$ and the experiment group $(\mathrm{m}=15.7)$, where $(\mathrm{p}$ value $=0.764, \mathrm{p}>0.05)$. This indicates that control group and experimental group were at the same level of proficiency of English before the module began. Thus, the sample of students chosen for the study was fair.

\subsection{Comparing Post-test Results Between Both Groups}

After conducting the experiment, a post-test was administered to the control group and experiment group to measure the influence of YouTube on developing elementary students' vocabulary. The following table shows the analysis of the post-test scores of the control group and experimental group.

Table 4. Analysis of the post-test scores of experimental and control group

\begin{tabular}{llllll}
\hline Post-Test & \multicolumn{5}{l}{} \\
\hline Group & $\mathrm{N}$ & Mean & SD & T. Value & P. Value \\
Control & 15 & 15.13 & 2.167 & & \\
Experimental & 15 & 20.80 & 1.897 & $-9.461-$ & 0.000 \\
\hline
\end{tabular}

The results of t-test show that there was a significant difference between the control group (m $=15.13)$ and the experiment group $(\mathrm{m}=20.80)$, where $(\mathrm{p}$ value $=0.000, \mathrm{p}<0.05)$. This indicates that utilizing of YouTube had a positive influence on the students' ability to understand the target vocabulary.

\subsection{Pre-test Versus Post-test Results}

In order to explore if the students acquire significant enhancement in their vocabulary recognition skills as an outcome of their learning for the duration of six weeks, a paired sample t-test was conducted to compare the means of the pre-test and post-test for students.

Table 5. Comparing of pre-test and post-test scores of both groups

\section{Pre-Test versus Post-Test}

\begin{tabular}{llllll}
\hline Group & $\mathrm{N}$ & Mean & SD & T. Value & P. Value \\
Pre-Test & 30 & 14.40 & 2.313 & & \\
Post-Test & 30 & 20.63 & 1.921 & $-16.219-$ & 0.000 \\
\hline
\end{tabular}




\section{Macrothink}

The results show that there was a significant improvement in vocabulary recognition and understanding among the students where ( $\mathrm{p}$-value $<0.05)$. That is the mean value for this group before lessons is $(m=14.40)$ compared to $(m=20.63)$ after the lessons.

The following histograms show the distribution of the results of pre-test and post-test for students respectively. In pre-test, the scores ranged from 11 to 18 out of 25, while the scores in post-test ranged from 17 to 24 out of 25. This indicates that YouTube as modern teaching tool influences positively on students to learn and recognize more vocabulary than traditional teaching methods.

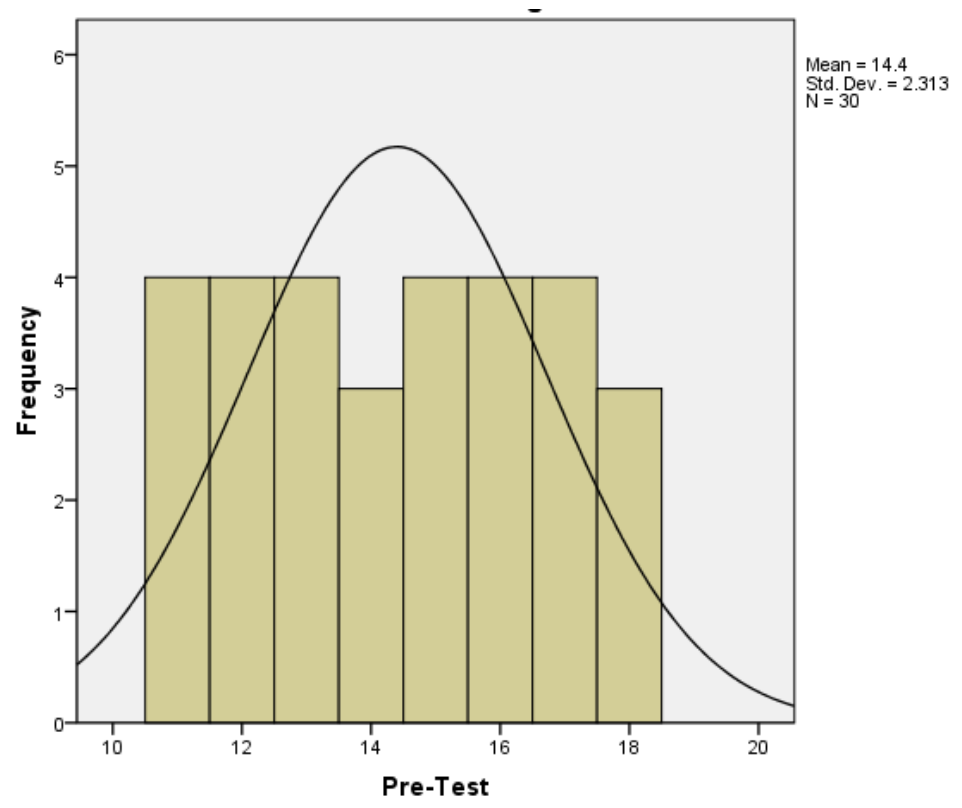

Figure 1. Pre-test results of both groups

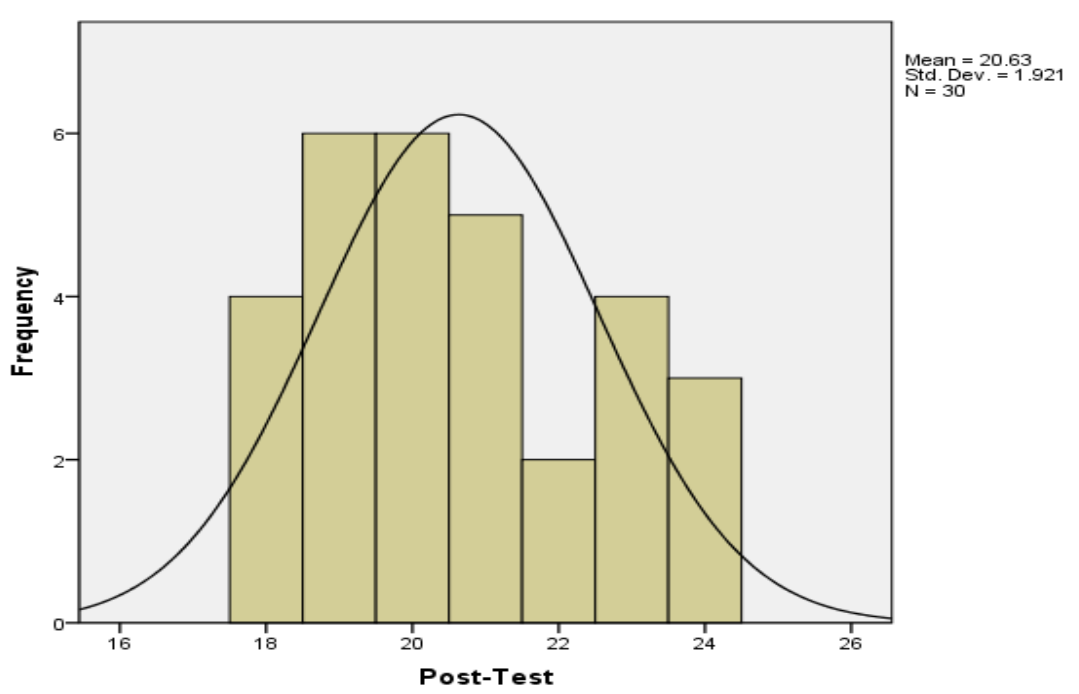

Figure 2. Post -test results of both groups

Therefore, YouTube videos have great potentials in developing and improving vocabulary 
knowledge for elementary students. This has been supported by several studies including Kabooha and Elyas (2018) who believe that YouTube considered as a useful tool for learning and the students are able to remember new vocabulary in very better way. Furthermore, Balcikanli (2011) reported that YouTube is an effective tool that facilitates students to retain the vocabulary that they learnt in the past without having to get bored. The results of such study confirmed the results of the study conducted by Abidin et al. (2011) which reported that YouTube helps students to improve their vocabulary competence compared to a traditional method.

However, the results of such study contradict with the findings reported by Tri and Nguyen (2014). They noted that most of students do not seem to see the high potential of technology as a modern teaching method in language learning. In addition, Jun Choi and Jonson (2005) and similarly, Amante and Enache (2011) found that YouTube motivated students to learn better more than using traditional teaching methods.

\section{Conclusion and Recommendations}

Using YouTube has become an important issue within the education field. This study examined the effect of YouTube videos on development of Jordanian elementary students' vocabulary comprehension skills. The findings of the study explored those differences between the achievement of the experimental group and the control group on the vocabulary comprehension test on using YouTube video to elementary students.

The findings of this study revealed that experimental group did better achievement in vocabulary comprehension than the control group. This indicates that integrating technology in teaching is of great importance and has positive effects. The quantitative data analysis showed that students who taught EFL vocabulary comprehension skills using YouTube videos have improved significantly than those who received the traditional instruction. The students in experimental group considered YouTube videos as enjoyable ways to teach and learn EFL vocabulary comprehension skill. They found them more interesting, motivational and beneficial.

However, YouTube video provides an opportunity for both students and learners to learn English language skills namely reading, writing, speaking, and listing which help them communicate with each other.

YouTube is an important tool to use it on education, YouTube videos is an easy, funny way to learn English language. Therefore, the results of current study support using YouTube videos in teaching and learning vocabulary for elementary students, YouTube has great potentials to reinforce EFL students' English language skills in all levels, specially writing vocabulary skill. Moreover, YouTube videos have the opportunities for students to make their interpretation and in the same time practice their writing skill.

This study suggested that both teachers and students can use YouTube creatively to achieve and enhance EFL in all levels.

Based on the findings of this study, some suggestions are summarized:

1) Conducting more studies to measure all other skills for males and females.

2) Conducting other studies to measure the influence of other technological tools on learning achievements for different educational level. 


\section{References}

Abidin, Z., Jafre, M., Pour-Mohammadi, M., Singh, B., Kaur, K., Azman, R., \& Souriyavongsa, T. (2011). The Effectiveness of Using Songs in YouTube to Improve Vocabulary Competence among Upper Secondary School Studies. Theory \& Practice in Language Studies, 1(11),45-56 . https://doi.org/10.4304/tpls.1.11.1488-1496

Almwajeh, M., \& Rababah, L. (2018). Literature is the best tool of awaking moral understanding and evaluation: Wendell Berry's The Long-Legged House. AWEJ for Translation \& Literary Studies, 2(2), 69-80. https://doi.org/10.2139/ssrn.3186984

Almwajeh, M., \& Rababah, L. (2019). There is more to it than meets the eye: an intercultural study of religious speech acts between Jordanian and American students. International Journal of Linguistics, 11(1), 34-45. https://doi.org/10.5296/ijl.v11i1.14261

Balcikanli, C. (2010, January). Long live, YouTube: L2 stories about YouTube in language learning. In Annals of Language and Learning: Proceedings of the 2009 International Online Language Conference (IOLC 2009), Universal-Publishers (p. 91).

Bonk, C. (2008). YouTube anchors and enders: The use of shared online video content as a macro context for learning. Retrieved January 1, 2020, from http://www.publicationshare. com/SFX7EED.pdf

Buzzetto-More, N. (2012). Social networking in undergraduate education. Interdisciplinary Journal of Information, Knowledge, and Management, 7, 63-90. https://doi.org/10.28945/ 1578

Buzzetto-More, N. (2014). An Examination of Undergraduate Student's Perceptions and Predilections of The Use of Youtube in The Teaching and Learning Process. Interdisciplinary Journal of E-Learning and Learning Objects, 10, 17-32. https://doi.org/10.28945/1965

Jdaitawi, M., Ishak. N., Izuddin. M., Rababah, L., Ibrahim, Y., \& Omar, O. (2012). Emotional Intelligence and Student Adjustment: Moderating Effect of Critical Thinking on Jordanian Students. International Journal of Business and Social Science, 6(11), 55-66.

Jun, H., \& Johnson, S. (2005). The effect of context-based video instruction on learning and motivation in online courses. The American Journal of Distance Education, 19(4), 215-227. https://doi.org/10.1207/s15389286ajde1904_3

June, S., Yaacob, A., \& Kheng, Y. K. (2014). Assessing the Use of YouTube Videos and Interactive Activities as a Critical Thinking Stimulator for Tertiary Students: An Action Research. International Education Studies, 7(8). https://doi.org/10.5539/ies.v7n8p56

Kabooha, R., \& Elyas, T. (2018). The effects of YouTube in multimedia instruction for vocabulary learning: Perceptions of EFL students and teaching. King Abdul Aziz university, Jeddah, Kingdom of Saudi Arabia. https://doi.org/10.5539/elt.v11n2p72

Mubaslat, M. (2012). The effect of using educational Games on the student's achievement in English language for the primary stage, Amman. Jordan. 


\section{I Macrothink}

Nico, M. (2003). Designers Can Save the World, New Design Magazine.

Rababah, I., \& Rababah, L. (2018). The actual use of brainstorming strategy among teachers of Arabic for speakers of other languages in writing classes. International Journal of English Linguistics, 9(1), 133-143. https://doi.org/10.5539/ijel.v9n1p15

Rababah, L. (2018). An adapted version of Torrance Test of Creative Thinking (TTCT) In EFL/ESL writing: A rubric scoring and a review of studies. International Journal of English and Education (IJEE), 7(2), 128-136.

Rababah, L. (2019a). Teachers' Integration of Information and Communication Technology (ICT) Tools into Writing Classes: A qualitative study. Journal of Education in Black Sea Region, 5(1), 30-36.

Rababah, L. (2019b). Using Collaborative Learning Strategies to Improve Creativity in EFL Writing: Attitudes and Actual Use. Journal of Education in Black Sea Region, 5(1), 36-52. https://doi.org/10.5296/elr.v5i1.14507

Rababah, L., \& Almwajeh, M. (2018). Promoting Creativity in EFL/ESL Writing through Scaffolding Strategy. International Journal of English and Education (IJEE), 7(3), 148-160.

Rababah, L., \& Bani Melhem, N. (2015). Investigation into Strategies of Creativity in EFL Writing in Jordan. Journal of Literature, Languages and Linguistics, 5(23), 14-25.

Rababah, L., \& Banikalef, (2019). The use of valuing strategies into enhancing creativity in EFL writing. Education and Linguistics Research, 5(1), 30-36. https://doi.org/10.5296/elr. v5i1.14507

Rababah, L., Alshehab, M., \& Bani Melhem, N. (2018). Exploring the Factors that Hinder Jordanian Students in Developing Creativity in EFL Writing. International Journal of English and Education (IJEE), 7(3), 161-170.

Rababah, L., Halim, A., Jdaitawi, M., \& Bani Melhem, N. (2013). The level of creativity in English writing among Jordanian secondary school students. Arts and Design Studies, 10, 25-29.

Richards, J. C. (2001). Curriculum development in language teaching. Cambridge, UK: Cambridge University Press. https://doi.org/10.1017/CBO9780511667220

Solanki, D., \& Shamlee, M. (2012). Use of Technology in English language teaching and learning: An Analysis, Communication skills. College of Engineering, Mumbai.

Vendoshi, R. (2005). Online Advertising, Master Thesis, University of Algiers.

Watkins, J., \& Wilkins, M. (2011). Using YouTube in the EFL Classroom. Language Education in Asia, 2(1), 55-67. https://doi.org/10.5746/LEiA/11/V2/I1/A09/Watkins_Wilkins 


\section{Macrothink

\section{Copyright Disclaimer}

Copyright reserved by the author(s).

This article is an open-access article distributed under the terms and conditions of the Creative Commons Attribution license (http://creativecommons.org/licenses/by/3.0/). 